\title{
THE ROLE OF LOCAL COMMUNITY AND ACADEMIC INSTITUTION TO EMPOWER THE SMALL ENTERPRISES IN THE URBAN AREA OF JAKARTA (INDONESIA)
}

\author{
Johannes Hamonangan SIREGAR ${ }^{1}$, Teddy Mohamad DARAJAT
}

DOI: 10.21163/GT_2019. 141.28

\begin{abstract}
:
The small and medium enterprises sector is important for economic and social development of a country. Indonesia government supported this sector in financial facility but many of enterprises are still difficult to develop their business even in urban area. Jakarta is the most populous city in Indonesia and as the economic and political capital of the country; it has attracted many people doing business such as small enterprises. Social activities and community involvement provides opportunities to develop self-knowledge and awareness of different strategies for the people doing business. The academic institution that provides basic knowledge of business can train them effectively using resources. The purpose of this study was to consider the role of local community and academic institution participation to empower the small enterprises in the urban area of Jakarta. The object of this study was to explore the potential creative product and social media of small business when develop from local community. The methodology of this study used qualitative data from interviews and observations, also supported by quantitative data from questionnaires. Based on the analysis of the activity awareness, usage and source of awareness of doing business, this study evaluates the limitation of small enterprises in the urban area of Jakarta, due to the problem of business knowledge in product and marketing activity. The results of this study conclude that the role of local community to develop SMEs can be used to inspire people to get involved in community for creative collaboration with academic institution.
\end{abstract}

Key-words: Creative Product, Small Medium Enterprises, Local Community, Urban Area.

\section{INTRODUCTION}

The informal sector entrepreneurship in traditional business has remained unchanged such small enterprises as practical personal life experience. Although they are accepted for their community which make them exist doing business, their business are viewed by some as inadequate by failing to engage their customers with their creative product and promote effective marketing for other community that will increase their profit.

Small and Medium Enterprises (SMEs) is important part for the development of country economic growth. Indonesia government encourages SMEs to develop their business by supporting financial loan with low-interest, such Credit for Business (in Indonesia language, Kredit Usaha Rakyat - KUR). Many people cannot obtain KUR because they assumed as "not bankable". In overcoming the difficulty of obtaining KUR for Jakarta citizens who do not meet the KUR requirements, Jakarta city administration

1 Universitas Pembangunan Jaya, Department of Information Systems, Pembangunan Jaya Center for Urban Studies; Bintaro Jaya, Sawah Baru, Ciputat, Tangerang Selatan 15413, Banten, Indonesia; johannes.siregar@upj.ac.id;

2 Universitas Pembangunan Jaya, Department of Product Design, Pembangunan Jaya Center for Urban Studies; Bintaro Jaya, Sawah Baru, Ciputat, Tangerang Selatan 15413, Banten, Indonesia; teddy.darajat@upj.ac.id 
opens opportunities for companies to participate in providing ease of lending process. This participation would make strong urban economy development in Jakarta city where the chance of many SMEs to growth their business becoming easy. The companies can participate to develop the city because of the budget of corporate social responsibility (CSR) and from Jakarta city administration these companies have chance to branding their products or services.

Much cooperation has been done between Jakarta city administration and companies. One of cooperation between the companies participation through CSR and Jakarta city administration that already in progress is RPTRA. RPTRA is short for Ruang Publik Terpadu Ramah Anak - Indonesia Language for Children-Friendly Integrated Public Space. Besides providing public space for children playing, RPTRA has multi functions uses, including uses for community activities, interaction among residents and training to residential community, also permitted as a place to held wedding reception or circumcision (Tobing, 2017). RPTRA as the local community has possibility to develop an understanding healthy living, to promote the quality of life and empowering own bussiness for Jakarta resident in their social process.

The role of local community can develop people for an inclusive social responsibility, community building and community development. Local community development needs to become a national interest, a part of the social charter between the State and its citizens (Sadan, 2004). The important of transport factors are considered (Ruda, 2014), because enterprises must act quickly and deliver their products as soon as possible. Local community which is neighbourhood area, transport constraint may not be included.

Jakarta city administration is interested in developing urban economics through RPTRA facilities with participation from private companies, and residents in local community. The key to the economic and societies are in part to the understanding with the increased importance and role in policy that cities have attained (Kresl, 2014).

This kind of participation is seen as having the potential for major benefits for the individual, the community, and for the society as a whole; as enabling decisions that are better able to fit the needs of the people and as making support for policies and programs more probable (Churchman and Sadan, 2004). Jakarta city administration has overall responsibility for policy and program development, and then invite private companies to support build RPTRA as the infrastructure facilities of local community.

PT Pembangunan Jaya is one of the companies that participated in Jakarta city administration project plan program to build RPTRAs. There are 6 (six) RPTRAs already built by PT Pembangunan Jaya in different places in Jakarta. The objective of this participation for PT Pembangunan Jaya is not only to build infrastructure facilities of RPTRAs, but also consider for empowering and developing community through RPTRA. Universitas Pembangunan Jaya (UPJ) as higher education institution, which is part of Pembangunan Jaya Group, assigned to conduct potential survey and data collection together with the local RPTRA board, for the purpose to empowering small enterprises around RPTRA in order to grow into successful entrepreneurs.

UPJ is involved dealing with the role of academic institutions of providing practical business training for small enterprises and human resource development for essential entrepreneurial skills in creative product and marketing techniques through social media. Human resources in training focused practices are associated with higher innovative performance (Beugelsdijk, 2008).

Cromie (Beugelsdijk, 2010) concludes there are seven characteristics that distinguish entrepreneurs from non-entrepreneurs. The following seven characteristics: Need for 
achievement; Locus of control; Risk taking; Creativity; Autonomy; Tolerance for ambiguity and self confidence. The need of achievement reflects entrepreneurs need to achieve the goal and refers to strive hard to attain success. The locus of control reflects entrepreneurs control the environment by the actions they take. The risk taking characteristic reflects entrepreneurs are considered to have a greater propensity to take risks. The creativity characteristic reflects entrepreneurs develop new ideas, spot market opportunities and recombine existing inputs in order to create added value. The autonomy characteristic reflects the ability of entrepreneurs to be self-directed in the pursuit of opportunity. The tolerance for ambiguity characteristic reflects entrepreneurs' ability to respond to deal effectively with situations that are vague, incomplete, unstructured, uncertain or unclear. The self-confidence characteristic reflects entrepreneurs' ability to mobilize the motivation, cognitive resources and courses of action needed to exercise control over events. These characteristics can be used to help to identify SME owners whose have a higher chance of developing their business. As they survive to grow into entrepreneurs, they can learn through practice and develop their habit of successful entrepreneurs. SME owners whose cannot develop their business, most of them have not been in formal education for doing business. They do their business as they tend to do the same thing as other people do. Creativity characteristic of SME owners is important in their successful business that involves their capabilities to produce creative product. The creative product which related to their business is identified by novelty and appropriateness (Saviolo, 2016).

Currently, as information technology use in business process, it is intuitive to expect information dissemination for new product. Information technology through social media is capable for marketing and sale purpose. This social media has its own value for Indonesia Government, especially in highlighting featured products in the context of increasing the value of Indonesian trade both in domestic and foreign markets (Tim Pusat Humas Kementerian Perdagangan RI, 2014).

In difficult situation of urban economy, creative product designs have a role to provide an alternative economic sector of society through a participative approach to offer alternative products that needed in the community such materials, technology with affordable prices (Sachari, 2002) or services like the shopping tourism (Egresi \& Kara, 2015).

The purpose of this study is to try to find information to help develop SMEs activities so that RPTRA community and UPJ participation will be better to support creative products and ways to promote products by social media, which play important roles in urban economy. Furthermore, this study aims to create new knowledge for studies based on the evaluation of how the problem of business knowledge in product and marketing activity are occurred in SMEs activity. To summarize, this study is to clarify the types of support needed by SMEs, find ways to develop SMEs activities in the future and form a basis for further studies.

\section{MATERIALS AND METHODS}

UPJ is given the opportunity to be actively involved to develop RPTRAs community that has been built by PT Pembangunan Jaya. This study considered one of those RPTRAs called "RPTRA Kenanga", which is located at Cideng urban village in Central Jakarta. RPTRA Kenanga has been awarded best performance RPTRA in Jakarta and could become 
a model of RPTRA. Besides facilitation for children, library, community meeting room and free $\mathrm{Wi}-\mathrm{Fi}$ are facilitated.

Since this study interested in emerging SMEs, for an exploratory purpose, respondents are selected for whom had not had business education or they know their business on what they are doing based on their experiences. The statistical method of this study is descriptive statistics using quantitative data with the small number of respondents and the characteristics of the respondents are chosen from RPTRA community. With the small number of respondents, this study enabled to find depth information of respondents from interview and have possibility to observe more clearly about respondents business activity.

The quantitative data from questionnaires is collected to support interview conducted by UPJ, on March 9, 2017 at RPTRA Kenanga. The number of respondents is 19 persons. Respondents are the owners of SMEs as member of RPTRA Kenanga community. From these data the limitation of SMEs will evaluate how the problem of business knowledge in product and marketing activity are occurred based on the activity awareness, usage and source of awareness of their business. The questionnaires contains 23 questions divided into four groups: characteristics of respondents (14 items), respondents activity awareness (4 items), type of business (4 items), and community activity (1 item).

Using the quantitative data, the qualitative data is collected from interviews and observations. The interview was held to discuss acivities ideas for the community and experiences of respondents, and then continued observations at the site of respondent behavior activities. The current and future need of activities in around RPTRA community is surveyed regarding to the members perception about successful entrepreneurs. In addition to the interviews, a group of selected community members and RPTRA Kenanga office staff and UPJ representatives discussed ways to enable the participation of community and institution to provide realistic and context-related programs on the wellbeing of SMEs and their needs for supports, the type of interaction is shown as Fig. 1.

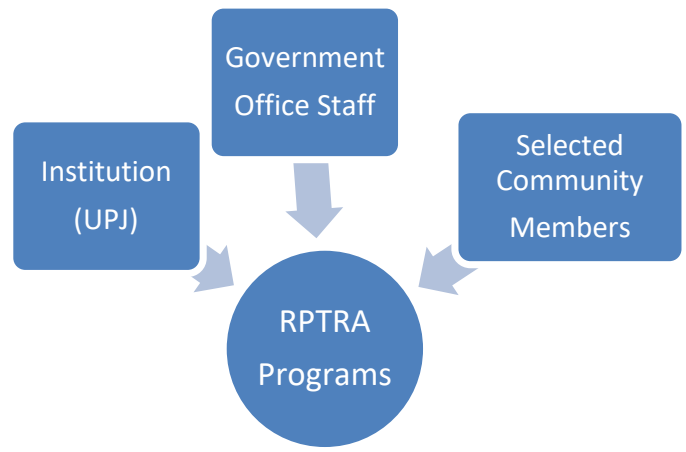

Fig. 1. The type of interaction in group discussion.

\section{RESULTS AND DISCUSSION}

The first step before interviews, the data from questionnaires is collected to describe the characteristics of respondents. All of 19 respondents are female, whose are the members of RPTRA community, and there are not many men involved with community organization. This condition shows that many people still thinking RPTRA community can only fulfil the needs of children for playing and health educational activities for mothers. 
Fig. 2 shows that the age after 40 years olds is most easy to do SME business for woman on the subjects that not bother with their family and not seek for career. The majority said their children already grown up, married and support them for doing business.

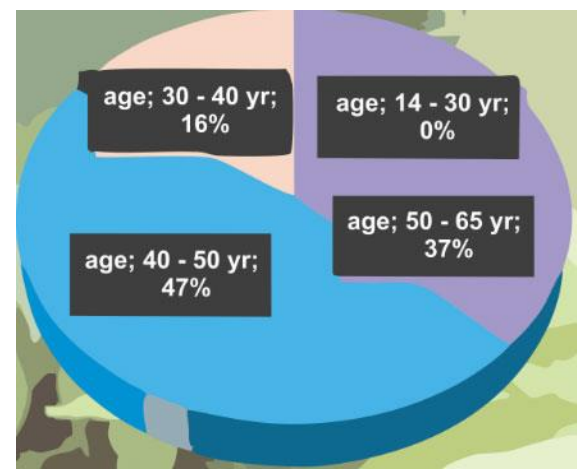

Fig. 2. The Age of Respondents.

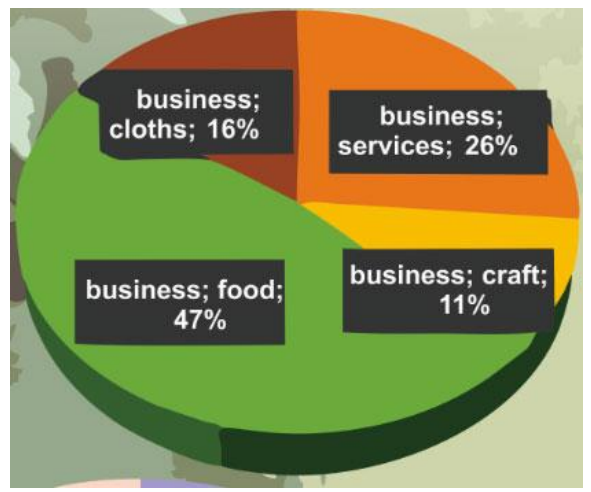

Fig. 3. The Type of SME Business.

The most interest type of business is food business, as shown in Fig. 3. Interestingly, even as the food maker has competitive challenge to sell their product, there is collaboration with them through community. In several comments for interview, the leader of women cooperation (called dapur RPTRA which means RPTRA's kitchen) in RPTRA Kenanga community mentions:

Cooperative aspect of RPTRA's kitchen if assisted, they can create more job vacancies. The collaboration among SMEs owners whose members of RPTRA community are gathering places for source of information, a good way to known each member, and also promotes their ideas and products. As urban village activities, we cannot accept for big order request, we always asked for food health permit must have and money responsibility as an official receipt. This cooperative work must have legal support.

As shown in Fig. 4, the business income that they have are more likely low income compared to the private business in their area, but it is enough to fulfil their daily life. The desire for freedom than making money which have motivated their business as respondents respond for interviewing about how to make larger their business: 
For me it would interest to do business as kind of social activity, making friends with time flexibility. I did not have expectation my business to become large companies. I wanted to have some freedom. I consider adding the quality of my food production. I need some of equipment to design the product more attractive for selling. I wanted to develop my product through sharing ideas in community meeting.

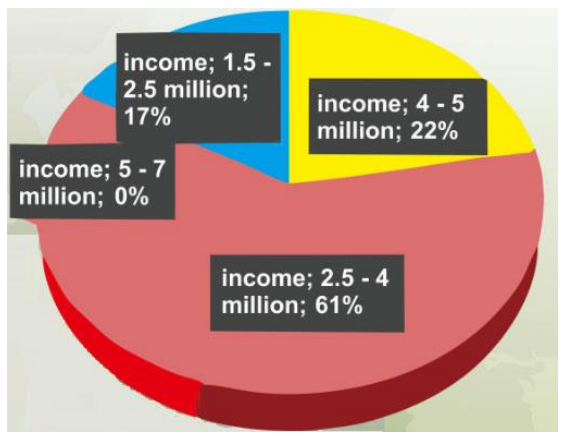

Fig. 4. The Business Income for a Month.

Activity awareness, which is awareness of the proportion of respondents wishes to have training for their business from UPJ.

Table 1. Topics of Activity Awareness.

\begin{tabular}{|l|c|c|c|}
\hline \multicolumn{1}{|c|}{ RPTRA Topic Activities } & TOM & Unaided & Aided \\
\hline Loan Aid & 16 & 0 & 16 \\
\hline Business Development & 2 & 9 & 1 \\
\hline Cleanliness & 2 & 0 & 2 \\
\hline Business Management & 2 & 2 & 5 \\
\hline Business Accounting & 0 & 0 & 0 \\
\hline Business Guidance & 0 & 4 & 4 \\
\hline
\end{tabular}

As shown in Table 1, a topic of the loan aid for business capital is most concerned as top of mind (TOM) awareness of respondents on the RPTRA activities, which means that the respondents need capital first before they develop their business. Unaided awareness means that the respondents' knowledge of activity without prompting, a topic of business development is most concerned. Aided awareness means that the respondents' knowledge of activity with prompting, a topic of business management is most concerned.

Jakarta city government on April 2017 launched Small Business Development Centre (SBDC) with the purpose to give capital assistance for small trader. There is capital loan agreement submission for fostered business group where PT Pembangunan Jaya is providing business assistance and training for small traders who joined in Jakarta's fostered business group (Folmer, 2017). The iinvolvement of organizational participants in the process of development SBDC is shown as Fig. 5. PT Pembangunan Jaya had initiatives to improve SMEs by SDBC and provided fund. UPJ community service program prepared the SBDC plan and program with RPTRA community. Then SBDC is inaugurated by Jakarta city government. For the loan aid capital activity awareness, respondents who joined in 
Jakarta's fostered business group through RPTRA can have capital aid by agreement of their group.

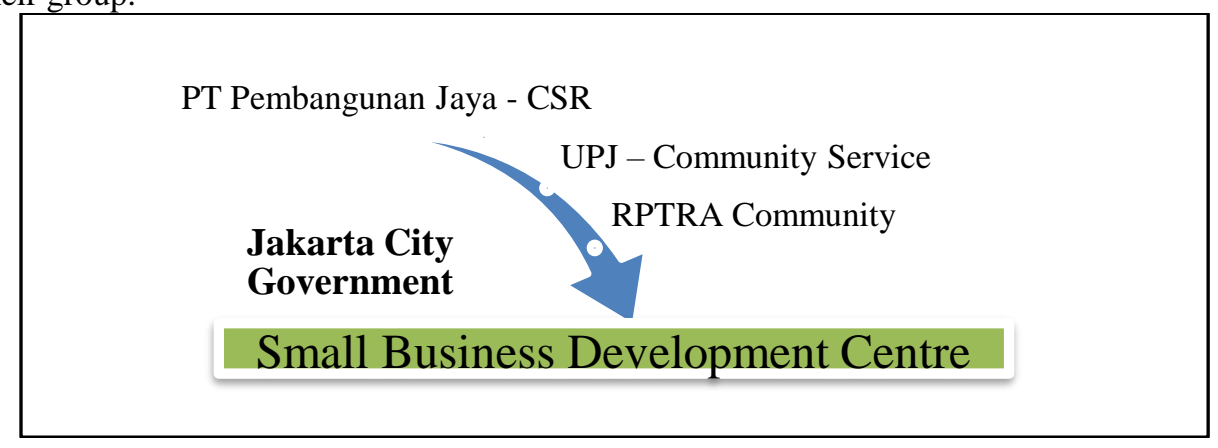

Fig. 5. Organizational participants in the process of development SBDC.

Another respondent also aware loan aid for business capital and have the desire to develop their business with creative product. The process how to change the activity more interesting that is the purpose of the respondent joined the community programs.

One respondent whose age was below 40 years, she is a member of the fostered business group, in her business development involves creative product, marketing by social media and network from RPTRA community. She combines some products mades by others, she has the passion for fashion and garment design that brings her started in activity to form a creative product to meet specific needs of customers. She offers her design products on social media, then many order come from outside of local community area, from other city and even from abroad. She wants to have a commitment and some support from institution to coach doing creativity of the entrepreneurship and to build web database. In this kind of activities, creativity characteristic is needed, collaboration with others and support from local community and institution are important.

The other respondents are work as a group for doing food catering business. When they received catering order form customer, they distribute the task to their member who have special skill to cook delicious food according the order, and when creative design to display their food is needed for that order, the members who have skill in food design are participated.

These evaluation results show the importance of creative characteristic for SMEs owners in creative product and using social media for marketing. This results lead to confirm the creativity characteristic that reflects entrepreneurs develop new ideas for their business (Beugelsdijk, 2010). The collaboration among members of RPTRA confirms the role of local community (Sadan, 2004) and UPJ as an academic institution participation doing consultation, training and coaching for small enterprises (Beugelsdijk, 2008).

This program of collaboration between community members, government office staff and institution is made possible through their commitment to support small traders to be involved in the process of nation's economic development.

\section{CONCLUSIONS}

This study has found that while SMEs owners are mostly concerned to have loan for business capital, the knowledge in business development, and business guidance are still 
need to be improved. With the help of Jakarta city government that provides Jakarta's fostered business group for loan assistance, they are able to develop their business. The analysis of this study suggests that collaboration with others, through local community would help SMEs business development, such as to do creative product, find resources, network and market.

The role of RPTRA to develop SMEs is able to inspire people in joining the community for creative collaboration with other members, and government institutions. This study contributes to a better understanding by SMEs about the role of RPTRA, and the support that the Academic Institution, such as the University Pembangunan Jaya, could help them in developing their business. Considering the small sample size for exploratory purpose in this study, the conclusions are not generalizable. Further study will be required by surveying other urban village areas, enlarge the samples, and strengthening the collaborative effort for SMEs development. The role of RPTRA is promising in order to empower the community to become qualified civil society in urban economy.

\section{R E F E R E N C E S}

Aji, H.S., Budiyanti, R.B., Djaja, K. (2016) The development of child-friendly integrated public spaces in settlement areas as an infrastructure of Jakarta, WIT Transactions on Ecology and the Environment, 210, 13-24.

Beugelsdijk, S. (2008) Strategic Human Resource Practices and Product Innovation, Organization Studies, 29 (6), 821-847.

Beugelsdijk, S. (2010) Entrepreneurial Culture, Regional Innovatives and Economic Growth, Entreprenuership and Culture, 124-154.

Churchman, A. \& Sadan, E. (2004) Public participation in environmental design and planning, Encyclopedia of applied psychology, 793-800.

Egresi, I., \& Kara, F. (2015) Predictors of tourists' shopping propensity: a case from Istanbul. Geographia Technica, 10 (2), 29-40.

Folmer (2017) Acting Gov. Inaugurated RPTRA's Small Business Development Center - Available from: http://www.beritajakarta.id/read/43471 [Accessed April 2017]

Kresl, P. K. (2014) Urban Economy, Economies, 2 (4), 218-219

Ruda, A. (2014) Spatial Decision Making for Logistic Centre Allocation, Geographia Technica, 09(2), 85-97.

Sadan, E. (2004) Empowerment and Community Planning: Theory and Practice, Translated from Hebrew by Richard Flantz, Hakibbutz Hameuchad Publishers, Tel Aviv.

Sachari, A. (2002) Sosiologi Desain, Penerbit ITB, Bandung

Saviolo, S. (2016) Managing Creativity and Creative Processes in Symbol-intensive Companies, EGEA, Milano

Tim Pusat Humas Kementerian Perdagangan RI (2014), Panduan Optimalisasi Media Sosial untuk Kementerian Perdagangan RI, Kementerian Perdagangan RI, Jakarta

Tobing, A.G.L. (2017) RPTRA, Multifunction for Community Activities, - Available from: http://www.beritajakarta.id/read/45565 [Accessed June 2017] 